Brit. J. industr. Med., 1965, 22, 21.

\title{
URINARY EXCRETION OF PHENOL BY MEN EXPOSED TO VAPOUR OF BENZENE: A SCREENING TEST
}

\author{
BY \\ S. G. RAINSFORD and T. A. LLOYD DAVIES \\ From H.M. Medical Inspectorate of Factories, Ministry of Labour, London
}

(RECEIVED FOR PUBLICATION JUNE 18, 1964)

\begin{abstract}
The metabolism of benzene differs from that of other aromatic hydrocarbons; the excretion of phenol in the urine of workers exposed to ambient benzene bears a linear relationship to the degree of exposure. A semi-quantitative screening test using stable reagents not requiring special apparatus or laboratory facilities permits an estimation of urinary phenolic bodies, and hence the exposure to benzene. The test may be used $(a)$ to determine whether individual workers need further investigation because of exposure to benzene, $(b)$ as a group test to determine whether the environment is acceptable, and $(c)$ to determine whether solvents often regarded as safe contain benzene.
\end{abstract}

Benzene is widely used in industry as a raw material in the manufacture of dyestuffs, explosives, and other chemicals, as a solvent for paints, varnishes, lacquers, fats, and rubber, as a constituent of paint strippers and adhesives, and in the blending of petrol. Grease-removing agents may contain benzene. Many solvents predominantly of the aromatic hydrocarbon series may contain appreciable quantities of benzene as a contaminant; for example, some grades of toluene may contain up to $11 \%$ of benzene.

Benzene has a high vapour pressure and, even when present in low proportions (less than $2 \%$ ), preferential evaporation into the air may in some circumstances create a hazard.

In the examination of factory atmospheres, the separation of benzene from other aromatic hydrocarbons, particularly toluene and xylene, requires special chemical methods. Additional complications arise from the difficulties of obtaining representative samples of the ambient atmosphere because of wide and rapid fluctuations of benzene concentrations.

The metabolic products of benzene are phenol, catechol, quinol, hydroxyquinol, trans-trans-muconic acid and L-phenylmercapturic acid (Porteous and Williams, 1949). The phenolic products are excreted in the urine conjugated as sulphates or glucuronides. In animals given benzene labelled with $\mathrm{C}^{\mathbf{1 4}}$, about $43 \%$ is excreted through the lungs. Of retained benzene, $23 \%$ is excreted as phenol, $3 \%$ as catechol, and $1 \%$ as quinol within two to three days. Excre- tion of phenol and catechol is almost completed within the first 24 hours, but other products may be excreted for 48 hours or longer. A little benzene may be slowly eliminated as carbon dioxide. Very probably, the toxic effects of benzene are due to phenol (Porteous and Williams, 1949). Toluene is metabolized to benzoic acid and then to hippuric acid, which is eliminated in the urine. The main metabolites of the xylenes are the corresponding isomers of toluic acid.

The different metabolic products of benzene, toluene, and xylene are of significance in the biological control of hazards arising from benzene. By making use of the body processes the need to distinguish benzene from other aromatic hydrocarbons is avoided, and by determining the urinary phenol excretion a measure of the overall absorption is obtained.

Pagnotto, Elkins, Brugsch, and Walkley (1961) observed that the urinary excretion of phenol by rubber-coating workers was linearly related to the atmospheric concentration of benzene to which they had been exposed. Walkley, Pagnotto, and Elkins (1961) showed that workers exposed for an eighthour day to an ambient concentration equivalent to 25 parts per million of benzene excreted approximately $200 \mathrm{mg}$. phenol/litre urine. This figure, however, was that adjusted for a hypothetical urinary specific gravity of $1 \cdot 024$. For a hypothetical specific gravity of 1.016, which Rainsford (1961) has shown is more appropriate to British workers, the critical 
level of phenol excretion will therefore be proportionately less, namely, about $150 \mathrm{mg}$. per litre of urine.

The previously published methods for estimating urinary phenols (Pagnotto et al., 1961; Walkley et al., 1961) are not convenient for routine use. The phenolic conjugates must be hydrolysed by acid at $100^{\circ} \mathrm{C}$. and steam distillation for 40 minutes, and the phenol estimated in the distillate by the colour formed with diazotized $p$-nitroaniline. This takes time and requires special apparatus; furthermore, the indicator is only stable for a few hours. We describe a method which requires little apparatus, using a stable reagent, and which is applicable to the rapid screening of many specimens of urine.

\section{Experimental}

The subjects of this survey were men and women exposed to the inhalation of benzol in the course of their usual work. Morning specimens of urine were collected either before or immediately after starting work. Evening specimens of urine were collected at the end of a working shift and, unless otherwise stated, eight hours after the morning specimen. With one exception, atmospheric benzol was estimated by spot samples taken during the course of the shift by Mr. S. G. Luxon, H.M. Chemical Inspector of Factories. Air was drawn through a bubbler containing selenic acid to remove homologues of benzol and then through another bubbler containing formalite reagent $(0.5 \mathrm{ml}$. of $40 \%$ formaldehyde to which is added $10 \mathrm{ml}$. of sulphuric acid). The brown colouration produced was matched against standard colours (Ministry of Labour, 1964).

Reagents. - The following reagents were used.

Diazotized p-nitroaniline (P.N.A.) was prepared as described by Walkley et al. (1961).

Gibbs' reagent (Gibbs, 1927): 2,6-dichloroquinone4-chloroimide, $0.05 \%$ in absolute ethyl alcohol. This is stable for six months or longer if stored in amber glass bottles in a cupboard at room temperature.

Alkaline borate buffer, $p \mathrm{H} 10 \cdot 15$, was prepared by mixing $75.4 \mathrm{ml}$. of a solution of sodium carbonate $(2.65 \mathrm{~g}$. anhydrous (A.R.) in $500 \mathrm{ml}$. water) with $24.6 \mathrm{ml}$. of a solution of sodium borate $\left(\mathrm{Na}_{2} \mathrm{~B}_{4} \mathrm{O}_{7} \cdot 10 \mathrm{H}_{2} \mathrm{O}\right)(9.55 \mathrm{~g}$. in $500 \mathrm{ml}$. in water).

Screening Test.-Urine $(1 \mathrm{ml}$.$) is placed in a glass-$ stoppered test-tube, and perchloric acid $(0.4 \mathrm{ml}$., $60 \%$ $\mathrm{w} / \mathrm{v}$ ) is added. The tube is placed in boiling water from which the heat has just been removed, left for at least $10 \mathrm{~min}$. to hydrolyse the phenolic conjugates, and then cooled rapidly under the cold tap to room temperature. Ether ( $4 \mathrm{ml}$.) is added, and the stoppered tube is inverted five times to extract the phenol. The ether is allowed to separate. Into the dimple of a porcelain tile is placed in order (1) alkaline borate buffer $(0.2 \mathrm{ml}$.), (2) $0.1 \mathrm{ml}$. of the separated ether layer, and (3) Gibbs' reagent $(0.05 \mathrm{ml}$. or
2 drops). A blue colour develops within 3 min., the intensity of which is related to the concentration of phenol, conjugated and free, in the urine.

Typical colours given by urine specimens are shown in Fig. 1 and are recorded as,,,- \pm+++ , and +++ . The colours are significantly different if aqueous solutions of phenol are used, i.e., aqueous standards do not provide a satisfactory basis for comparison. A transient purplish colour is often observed before the final colour develops. This should be ignored.

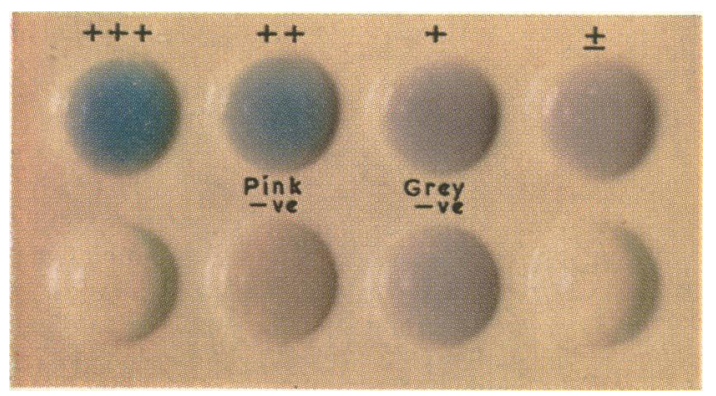

FiG. 1.-Colour reactions in the screening test. $t++, 320 \mathrm{mg} . / 1$; ,++ 138 mg./l.; +, 94 mg./l.;, \pm 66 mg./1.; -, grey, 26 mg./l.; - , pink, $17 \mathrm{mg} . / 1$. Negative values may be either grey or pink. Positives are always definitely blue.

Validation of the Method.-Only limited amounts of strong mineral acid may be used when ether is the subsequent extractant.

Perchloric acid was the most effective and rapid of the many mineral acids tested. The combined efficiency of hydrolysis with perchloric acid and extraction with ether was tested by analysing urines for phenol using these methods of hydrolysis and separation, but estimating the phenol with P.N.A. and comparing the results with those obtained by the method of Pagnotto et al. (1961). The results agreed well (Fig. 2) except that our method gave results about $10 \%$ lower at the higher levels of phenol. Ether extraction was shown to be $92 \%$ to $100 \%$ efficient, so that this discrepancy can probably be attributed to incomplete hydrolysis by our shorter method when higher concentrations of phenol are present. Accordingly, if the urine was diluted, the correct results were obtained (Table 1).

The P.N.A. reagent and Gibbs' reagent gave the same results when used on aqueous solutions of pure phenol. For this comparison borate buffer $(5 \mathrm{ml}$.) and Gibbs'

TABLE 1

EFFECT OF DILUTING URINE SPECIMENS ON ESTIMATED PHENOL CONTENT

\begin{tabular}{l|c|c}
\hline Sample of Urine & $\begin{array}{c}\text { Phenol } \\
\text { (mg./l. urine) } \\
\text { (Method of Pagnotto } \\
\text { et al. (1961) ) }\end{array}$ & $\begin{array}{c}\text { Rapid Hydrolysis } \\
\text { with Perchloric Acid } \\
\text { Ether Extraction } \\
\text { (P.N.A. as indicator) }\end{array}$ \\
\hline A Undiluted & 245 & 184 \\
A1 A diluted $\times \frac{1}{2}$ & 185 & 120 \\
B Undiluted $\times \frac{1}{2}$ & - & 190 \\
B1 B diluted $\times \frac{90}{2}$ & \\
\hline
\end{tabular}


FIG. 2.-Determination of phenol in urine estimated by the method of Pagnotto $e t$ al: (1961) compared with rapid hydrolysis with perchloric acid and extraction with ether (P.N. A. as indicator).

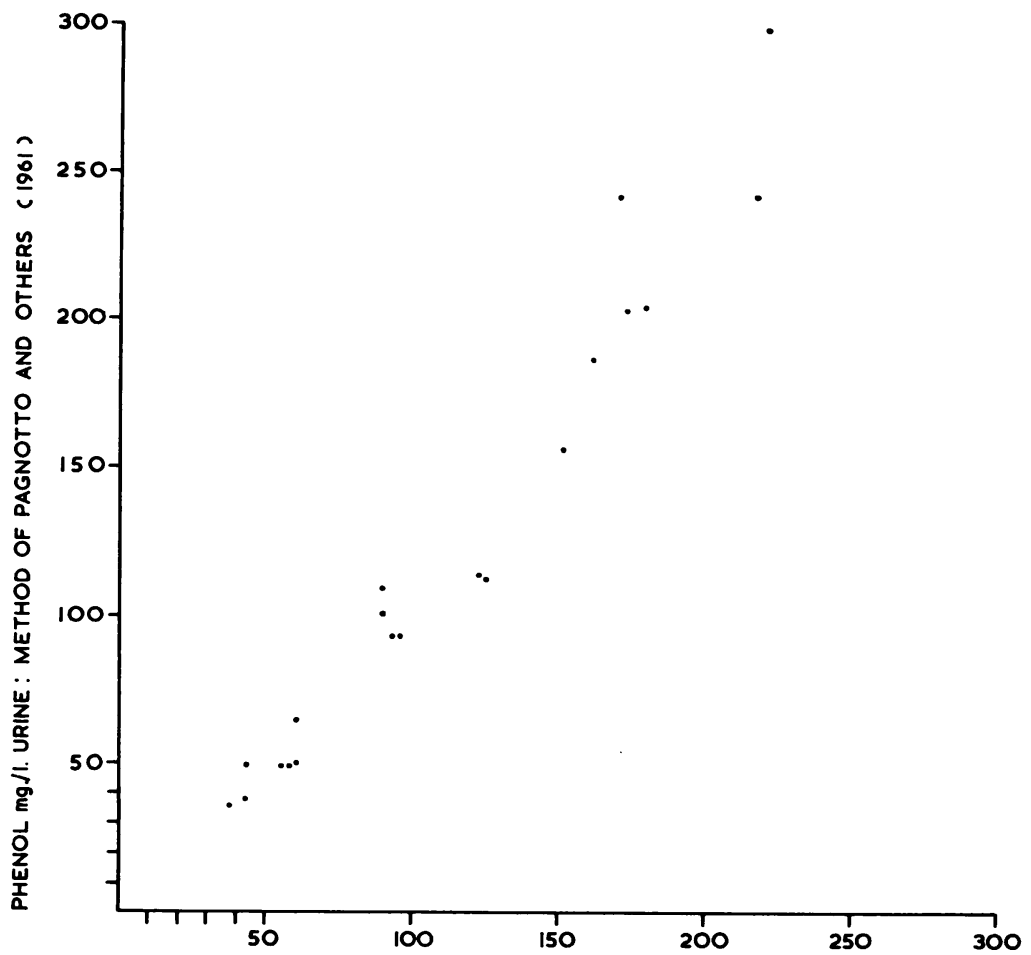

PHENOL mg.h. URINE : RAPID HYDROLYSIS WITH PERCHLORIC ACID, EXTRACTION WITH ETHER : P.NA. AS INDICATOR

reagent $(2 \mathrm{ml}$.$) were added to aqueous phenol (10 \mathrm{ml}$.$) ,$ the mixture was allowed to stand for one hour, the volume was made up to $25 \mathrm{ml}$., and the absorption was measured on a spectrophotometer (Cambridge SP600) at $600 \mathrm{~m} \mu$. The absorption was compared with a calibration curve.

The two reagents were compared on urine specimens from which the phenol had been separated by steam distillation after acid hydrolysis, as described by Walkley et al. (1961), except that perchloric acid was used for the hydrolysis. At least $100 \mathrm{ml}$. of distillate was obtained from $10 \mathrm{ml}$. of urine. Both reagents gave consistent results, but the concentrations estimated by the Gibbs' reagent were about one-third less than those obtained with P.N.A. (Fig. 3). This suggests that steam distillates of acid-hydrolysed urine may contain metabolites other than phenol which give a colour with P.N.A. but not with Gibbs' reagent, and that P.N.A. is not sufficiently specific for phenol. This lack of specificity was also found by Walkley et al. (1961). When urines of low specific gravity $(<1.012)$ were analysed the two methods gave closer results, and the reverse happened when urines of high specific gravity $(<1.024)$ were analysed. The values also became closer as the concentration of the phenol increased, and with urines containing more than $200 \mathrm{mg}$. phenol/l. they seldom differed by more than $10 \%$.
Correction for the Specific Gravity of Urine.-For a given quantity excreted, the concentration of phenol is proportional to the amount by which the specific gravity of the urine exceeds unity. Walkley et al. (1961) adjusted their results to a specific gravity of $1 \cdot 024$. For British workers, adjustment to a specific gravity of 1.016 is more realistic (Rainsford, 1961). In terms of the screening test, however, such adjustment normally makes little difference (Table 2). The test can, if desired, be modified with advantage by dividing the urines into three classes with two specific gravity beads, $1 \cdot 012$ and $1 \cdot 024$. Urines with

TABLE 2

ADJUSTMENT OF RESULTS FOR VARIATIONS IN THE SPECIFIC GRAVITY OF THE URINES

\begin{tabular}{c|c|c|c|c}
\hline \multirow{2}{*}{ Urine } & \multicolumn{3}{c|}{ Phenol (mg./1.) } & \\
\cline { 2 - 4 } & $40-50$ & $51-100$ & $101-150$ & $<150$ \\
\hline $\begin{array}{c}\text { Uncorrected for } \\
\text { specific gravity }\end{array}$ & 26 & 16 & 29 & 18 \\
$\begin{array}{c}\text { Adjusted to specific } \\
\text { gravity of 1.016 }\end{array}$ & 25 & 19 & 25 & 20 \\
\hline Screening test & - or \pm & + & ++ & +++ \\
& 26 & 16 & 29 & 18 \\
\hline
\end{tabular}

Phenol determinations were carried out by the method of Pagnotto et al. (1961). The number of specimens in each concentration range et al. (1961). The number of specimens
before and after correction is given. 


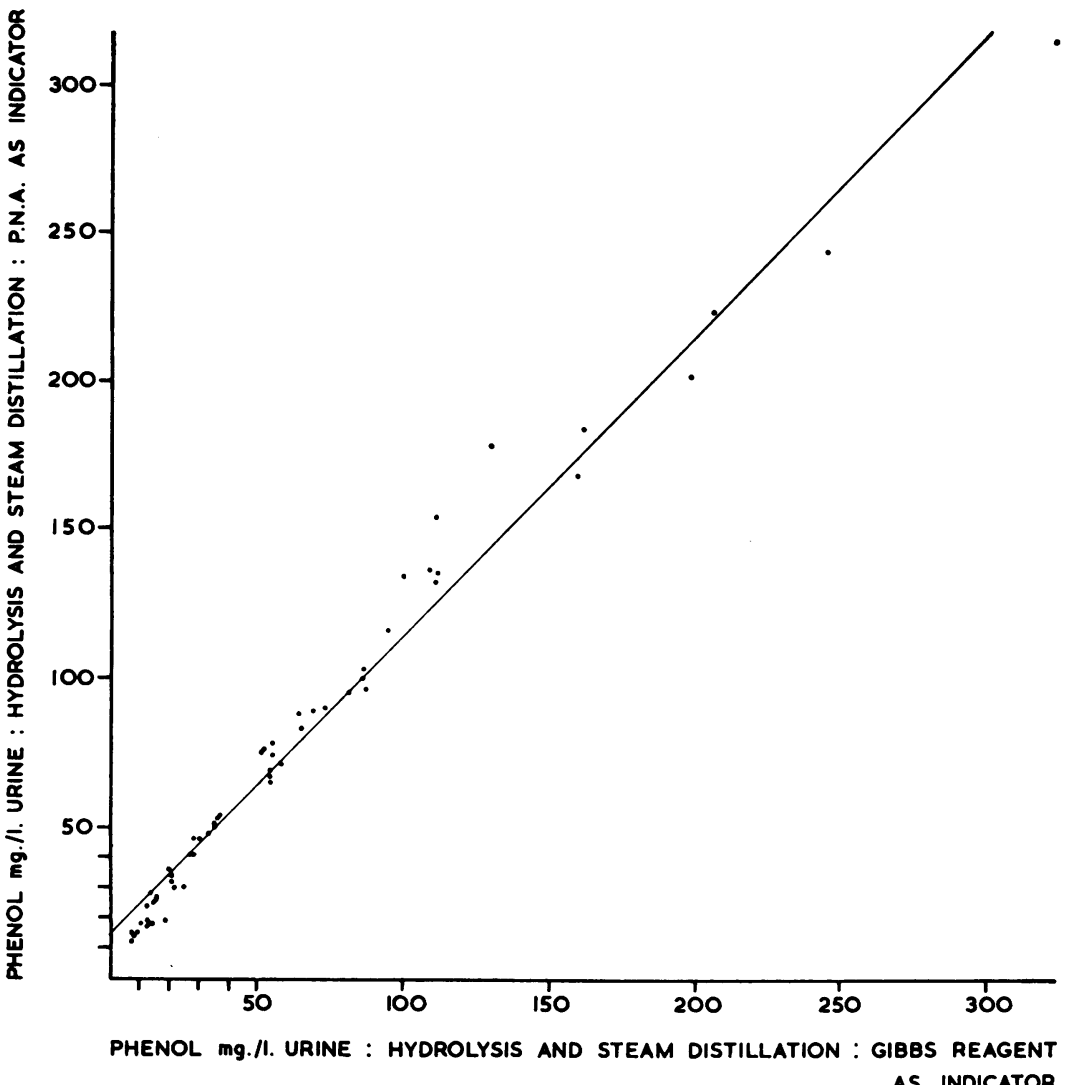

Fig. 3.-Shows constant relationship between P.N.A. and Gibbs' reagent in the determination of phenol in urine after acid hydrolysis and steam distillation.

TABLE 3

intermediate specific gravity are tested as described. For those below 1.012 , only $2 \mathrm{ml}$. of ether is used for extraction; and for those above 1.024, the volumes of urine and perchloric acid taken are halved but the amount of ether used is $4 \mathrm{ml}$. For dense urines the latter procedure gives markedly clearer colours.

Aberrant Results.-Three out of 209 specimens of urine obtained from workers before exposure to benzene gave a brilliant green colour with the screening test. When urines were taken from these three workers after eight hours' exposure to benzene normal positives were obtained.

False positives were obtained only with specimens which had been allowed to stand on the bench at room temperature and in which considerable bacterial growth was present when they were submitted to the test. Table 3 shows that false positives arise from the extraction by ether of some colour-forming material in our method, since when steam distillation is substituted the false positives are not obtained. That this was an effect of bacterial action was confirmed by contaminating with an indolproducing coliform organism a specimen of urine known to contain very little phenol and leaving it to stand for two days. After two days the apparent phenol content had increased sixfold (Table 4). Fresh specimens of urine
INCREASE IN APPARENT PHENOL CONTENT OF URINE AFTER STORAGE

\begin{tabular}{c|c|c}
\hline \multirow{2}{*}{$\begin{array}{c}\text { After standing on } \\
\text { bench for } \\
24 \text { to 36 hours }\end{array}$} & $\begin{array}{c}\text { Method of Pagnotto } \\
\text { et al. (1961) }\end{array}$ & $\begin{array}{c}\text { Rapid Hydrolysis } \\
\text { with Perchloric Acid } \\
\text { Ether Extraction } \\
\text { (P.N.A. as indicator) }\end{array}$ \\
\cline { 2 - 3 } & 16 & 80 \\
Urine 1 & 67 & 120 \\
Urine 2 & 24 & 76 \\
\hline
\end{tabular}

TABLE 4

APPARENT INCREASE IN PHENOL CONTENT OF URINE CONTAMINATED WITH INDOL-PRODUCING BACTERIA

\begin{tabular}{c|c|c}
\hline \multirow{2}{*}{$\begin{array}{c}\text { Urine Sample } \\
\text { (hr. after } \\
\text { contamination) }\end{array}$} & $\begin{array}{c}\text { Method of Pagnotto } \\
\text { et al. (1961) }\end{array}$ & $\begin{array}{c}\text { Rapid Hydrolysis } \\
\text { with Perchloric Acid } \\
\text { Ether Extraction } \\
\text { (P.N.A. as indicator) }\end{array}$ \\
\cline { 2 - 3 } & 12 & 12 \\
\hline Fresh & 11 & 56 \\
$24 \mathrm{hr}$. & 11 & 75 \\
\hline $48 \mathrm{hr}$. & &
\end{tabular}


must be used or, alternatively, perchloric acid should be added to the urine in the proportion described soon after the specimen is passed.

\section{Results}

To date 209 specimens of urine have been submitted to the screening test, and the results have been compared with those obtained using P.N.A. as the reagent (Table 5). Of the 73 specimens giving ++

TABLE 5

RESULTS BY THE SCREENING TEST COMPARED WITH PHENOL CONCENTRATIONS ESTIMATED IN THE URINES OF WORKERS BY THE METHOD OF PAGNOTTO ET AL. (1961)

\begin{tabular}{|c|c|c|c|c|c|c|}
\hline \multirow{2}{*}{$\begin{array}{c}\text { Urine Phenol } \\
\text { (mg./l., method of } \\
\text { Pagnotto et al. } \\
(1961) \text { ) }\end{array}$} & \multicolumn{5}{|c|}{ Screening Test Reactions } & \multirow{2}{*}{ Total } \\
\hline & - & \pm & + & ++ & +++ & \\
\hline $\begin{array}{l}11-20 \\
21-30\end{array}$ & \multirow{11}{*}{$\begin{array}{c}24 \\
11 \\
(2 \text { green) } \\
14 \\
12 \\
\text { (1 } 12 \text { green) } \\
6 \\
4 \\
3 \\
= \\
= \\
= \\
= \\
= \\
= \\
= \\
-\end{array}$} & $\begin{array}{l}2 \\
2\end{array}$ & $\begin{array}{l}0 \\
2\end{array}$ & 二 & 二 & $\begin{array}{l}26 \\
15\end{array}$ \\
\hline $\begin{array}{l}31-40 \\
41-50\end{array}$ & & $\begin{array}{l}8 \\
4\end{array}$ & 2 & 二 & $\overline{-}$ & $\begin{array}{l}24 \\
16\end{array}$ \\
\hline $\begin{array}{l}51-60 \\
61-70\end{array}$ & & $\begin{array}{l}4 \\
1 \\
4\end{array}$ & $\begin{array}{l}3 \\
3 \\
7\end{array}$ & $\bar{z}$ & $=$ & $\begin{array}{r}13 \\
8 \\
14\end{array}$ \\
\hline $81-90$ & & 3 & 3 & 3 & - & 9 \\
\hline $\begin{array}{r}91-100 \\
101-120\end{array}$ & & 1 & 4 & 12 & -1 & 17 \\
\hline $\begin{array}{l}101-120 \\
121-140\end{array}$ & & ב & $\begin{array}{l}3 \\
4\end{array}$ & 8 & $\begin{array}{l}1 \\
5\end{array}$ & $\begin{array}{l}12 \\
16\end{array}$ \\
\hline $141-1$ & & - & i & 2 & - & 3 \\
\hline $\begin{array}{l}161-1 \\
181-2\end{array}$ & & - & 1 & 3 & $\overline{2}$ & $\begin{array}{l}3 \\
6\end{array}$ \\
\hline & & - & 1 & 5 & 9 & 14 \\
\hline & & & 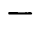 & 2 & 6 & 8 \\
\hline & & & & & & \\
\hline Total & 74 & 29 & 33 & 46 & 27 & 209 \\
\hline
\end{tabular}

or +++ reactions, 58 contained more than $100 \mathrm{mg} . / \mathrm{l}$, and all contained more than $80 \mathrm{mg} . / 1$. Conversely, out of 67 specimens containing more than $100 \mathrm{mg}$./l., 58 gave ++ and +++ reactions, and the rest gave + reactions. All 103 specimens giving - or \pm reactions contained less than $100 \mathrm{mg}$./l. As already shown (Table 2), correc- tion for the specific gravity of the urine did not affect the comparison materially.

A comparison was made between phenol excreted in the urine and exposure as measured by the estimation of benzene in the atmosphere (Table 6). A broad correlation was found in accordance with the work of Pagnotto et al. (1961). A close correlatio n could not be expected since all our subjects continued with their usual work and most spent substantial intervals of time in uncontaminated air.

\section{Discussion}

The screening test described for phenol in urine allows a fairly precise estimate to be made of the degree of exposure of workers to benzene vapour. The results are not directly comparable with those of Walkley et al. (1961) and of Pagnotto et al. (1961). Their method, using diazotized $p$-nitroaniline (P.N.A.) reagent, gives results about 1.5 times higher than ours. Perhaps one-fifth of this difference can be accounted for by incomplete hydrolysis of the phenolic conjugates by our much shorter method, but most of the difference is due to the lack of specificity of the P.N.A. reagent, which gives a colour with metabolites other than phenol. In this respect, our method using Gibbs' reagent is more specific. An eight-hour exposure to 25 p.p.m. of benzene in air leads to the excretion of a phenolic concentration recorded as $200 \mathrm{mg}$. $/ \mathrm{l}$. at a specific gravity of 1.024 by Walkley's method and as $100 \mathrm{mg}$./1. at a specific gravity of 1.016 by our method.

The maximum allowable concentration of benzene vapour in air is 25 p.p.m. for an eight-hour day (Ministry of Labour, 1961). In our test, + readings indicate that this exposure has been approached and possibly exceeded, and ++ readings indicate that it has almost certainly been exceeded.

TABLE 6

COMPARISON OF URINARY PHENOL AND ATMOSPHERIC CONCENTRATION OF BENZENE

\begin{tabular}{|c|c|c|c|c|c|c|c|}
\hline \multirow[t]{2}{*}{ Factory } & \multirow{2}{*}{$\begin{array}{c}\text { No. of } \\
\text { Workers } \\
\text { Examined }\end{array}$} & \multicolumn{2}{|c|}{$\begin{array}{c}\text { Phenol Excretion } \\
\text { Before Exposure } \\
\text { (mg./l.) }\end{array}$} & \multicolumn{2}{|c|}{$\begin{array}{l}\text { Phenol Excretion } \\
\text { After Exposure } \\
\text { (mg./l.) }\end{array}$} & \multirow{2}{*}{$\begin{array}{c}\begin{array}{c}\text { Benzol in Air } \\
\text { Concentrations } \\
\text { (p.p.m.) }\end{array} \\
\text { Range }\end{array}$} & \multirow{2}{*}{$\begin{array}{l}\text { Length o } \\
\text { Exposure } \\
\text { (hr.) }\end{array}$} \\
\hline & & Range & Mean & Range & Mean & & \\
\hline $\begin{array}{l}1^{*} \\
2 \\
3 \\
4 \\
5 \\
6 \\
7 \\
8 \\
9 \\
10 \\
11 \\
12 \\
13\end{array}$ & $\begin{array}{r}30 \\
2 \\
5 \\
6 \\
8 \\
10 \\
8 \\
7 \\
6 \\
5 \\
5 \\
14 \\
3\end{array}$ & $\begin{array}{l}17-40 \\
12-29 \\
20-44 \\
21-37 \\
25-46 \\
24-144 \\
37-98 \\
41-91 \\
21-56 \\
59-117 \\
52-111 \\
19-69 \\
-\end{array}$ & $\begin{array}{l}28 \\
16 \\
31 \\
27 \cdot 5 \\
37 \\
52 \\
55 \\
60 \\
37 \\
79 \\
68 \\
39 \\
-\end{array}$ & $\begin{array}{r}19-74 \\
19-44 \\
28-48 \\
19-55 \\
52-124 \\
14-176 \\
60-195 \\
61-310 \\
50-254 \\
107-210 \\
87-224 \\
113-278 \\
82-188\end{array}$ & $\begin{array}{l}31 \\
31 \\
37 \\
37 \cdot 5 \\
74 \\
87 \\
100 \\
126 \\
129 \\
140 \\
140 \\
177 \\
132\end{array}$ & \begin{tabular}{|c|}
$<10^{*}$ \\
$<10$ \\
$<10$ \\
$<10$ \\
$7 \cdot 5-50$ (average 24) \\
$7-15$ \\
$12-15$ \\
$40-60$ \\
$10-70$ \\
$10-70$ \\
$20-80$ \\
$25-150$ \\
$>500$
\end{tabular} & $\begin{array}{c}8 \\
8 \\
8 \\
8 \\
8 \\
8 \\
8 \\
8 \\
8 \\
6 \\
8 \\
5-6 \\
1\end{array}$ \\
\hline
\end{tabular}

*This factory was employing toluol containing less than $0.2 \%$ of benzene. 
The application of the screening test is limited by two considerations. If the urine is allowed to stand so that it becomes infected with bacteria a false high phenolic content is likely to be recorded; and, as the excretion of phenol from absorbed benzene is substantially complete in $24 \mathrm{hr}$. (Porteous and Williams, 1949), only exposure incurred shortly before the urine specimen is passed can be estimated. Even so, a better estimate can be obtained than by air sampling, as atmospheric benzene concentrations tend to vary rapidly.

Information from the screening test can be applied in three ways. First, if an individual worker shows repeated positive tests, fuller clinical and pathological enquiries should be instigated. Secondly, if more than a small proportion of workers show positive tests the environment should be corrected. Thirdly, the tests should reveal whether solvents wrongly regarded as safe contain benzene in sufficient quantities to be hazardous.

We wish to thank Mr. S. G. Luxon, H.M. Chemical Inspector of Factories, for the estimation of benzene in factory atmospheres, and Mr. A. A. Cernik for technical assistance. We are grateful to Mr. A. J. Goodfellow for undertaking the benzene estimation in one factory.

\section{REFERENCES}

Gibbs, H. D. (1927). J. biol. Chem., 72, 649.

Ministry of Labour (1961). Toxic Substances in Factory Atmospheres (Safety, Health and Welfare, New Series No. 8, Amendment No. 2), H.M. Stationery Office.

Ministry of Labour (1964). Detection of Toxic Substances in Factory Atmospheres-Benzene. (In the press.)

Pagnotto, L. D., Elkins, H. B., Brugsch, H. G., and Walkley, Janet E. (1961). Amer. industr. Hyg. Ass. J., 22, 417.

Porteous, J. W., and Williams, R. T. (1949). Biochem. J., 44, 46.

Rainsford, S. G. (1961). In Proc. XIII Int. Congr. Occup. Hith, 1960, p. 345 .

Walkley, Janet E., Pagnotto, L. D., and Elkins, H. B. (1961). Amer. industr. Hyg. Ass. J., 22, 362. 